\title{
A Prospective Study on Building Quality: Relationship between Workmanship Quality and Common Building Defects of Low-cost Construction Projects
}

\author{
M.A. Othuman Mydin ${ }^{1, a}$, N.A. Othman ${ }^{2}$, N. Md. Sani ${ }^{3}$ \\ ${ }^{1,2,3}$ School of Housing, Building and Planning, Universiti Sains Malaysia, 11800 Penang, Malaysia
}

\begin{abstract}
This study focuses on the quality of workmanship in the construction of lowcost housing in Kedah and Penang State, Malaysia and its relation to defects occurring in the building. The objectives of this study are to investigate common building defects that mostly occur at low-cost housing due to poor workmanship, the factors that contribute to poor workmanship and to established possible measures to minimize these problems. From the combination of literary reviews and questionnaire surveys, this research explores all the stated objectives. For this particular study, quantitative research was conducted through questionnaire surveys involving respondents who are involved in and are experienced in working on construction projects. After analysing the data, this study found that most common defects occurring on low-cost housing are cracks on walls, settlement and peeling paint. Additionally, construction of low-cost housing commonly suffers from low quality workmanship due to poor project management and a lack of experience and competency among labourers. These significant impediments can be remedied by providing training and education to the labourers as well as implementing strict supervision during construction work.
\end{abstract}

\section{Introduction}

The construction sector contributes greatly to the economies of growing countries, including Malaysia [1]. However, the quality of certain construction projects in Malaysia does not always meet expectations [2]. The construction industry today has undergone numerous setbacks such as a decrease in standards of quality, rises in costs and delays in construction projects [3]. Poor quality work on construction projects is a common phenomenon in throughout the world. Countless disputes take place between clients, homeowners and other parties involved in construction (especially contractors), typically over cases of building defects. Defective work in construction projects could be seen as incompliance or lack of conformity with contract agreements which include: project drawings, specifications, quality of workmanship, and any other conditions not expressly stated such as "durability, aesthetics, performance or design" [4]. Particular weak points in the construction sector in Malaysia include a lack of skills or efficient training for the construction work being done and insufficient status acknowledgement of construction technologist [2].

\footnotetext{
${ }^{\mathrm{a}}$ Corresponding author : azree@usm.my
} 
Housing is a major concern for people in every corner of the world as the wellbeing of a country is reflected in whether its people enjoy a certain standard of living. Residential and neighbourhood satisfaction is an important indicator of housing quality and conditions which affects an individual's quality of life. However, in recent years, there several issues have arisen involving low-cost housing. These have mainly involved quality problems and building defects of low-cost housing. Defects may be considered as a failing or shortcoming in the function, performance, statutory or user requirement of a building, and might manifest itself within the structure, fabric, services or other facilities of the affected building [5]. Defects that mostly commonly occur on low-cost housing structures are peeling paint, cracks on wall, mould growth, dampness, leakage, settlement, faulty installation of sanitary and electrical fittings, broken tiles and unevenness of floor finishes and wall plasters [6]. Along with these factors, another one seems to contribute to the problem is poor workmanship quality during construction [7]. Most defects in construction projects are due to human error. In other words, those involved in the construction of a structure are generally to blame for human error leading to poor quality work. Workmanship has been classified as one of the most frequent factors of nonconformance on construction sites and, therefore, through a review of relevant literature, eight variables related to the causes of poor quality workmanship on construction projects were found. This study's focus is on the factors that contribute to poor workmanship with a goal of establishing possible measures to overcome such problems.

\section{Methodology}

This study focused on the causes of defects that occurred on low-cost housing built in Sungai Petani, Kedah. The study began with a review of literature related to the research topic. Then, site observations were carried out to investigate commonly occurring defects involving three low-cost housing areas in Sungai Petani, namely, Bandar Puteri Jaya, Ambangan Heights Zon Mawar and Flat PPR Paya Nahu. During the site observations, pictures of defects were taken. The main source of data collection for this study was through questionnaire surveys. Due to time restrains, the survey was only carried out in Kedah and Penang with the targeted respondents being those involved in the field of construction such as building surveyors, architects, quantity surveyors, project managers, engineers, contractors and site supervisors. The data from 180 respondents were recorded and analysed. Tables and bar graphs were employed to clearly present the data, the analysis of which was carried out using mean item scores to rank the degree of importance for the factors contributing to poor workmanship and the degree of effectiveness of possible measures to overcome quality problems.

\section{Site Observation, Questionnaire Analysis and Discussion}

\subsection{Site Observation}

\subsubsection{Bandar Puteri Jaya}

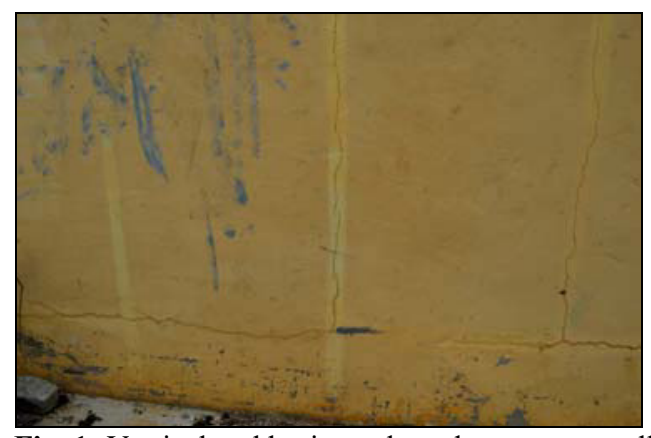

Fig. 1: Vertical and horizontal cracks on outer wall

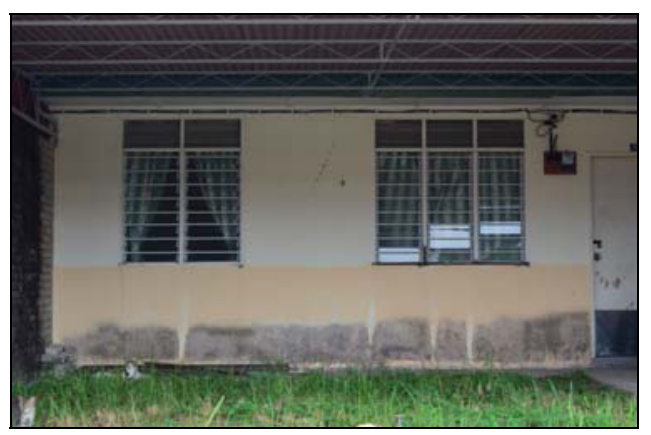

Fig. 2: Peeling paint on external wall 


\subsubsection{Ambangan Heights Zon Mawar}

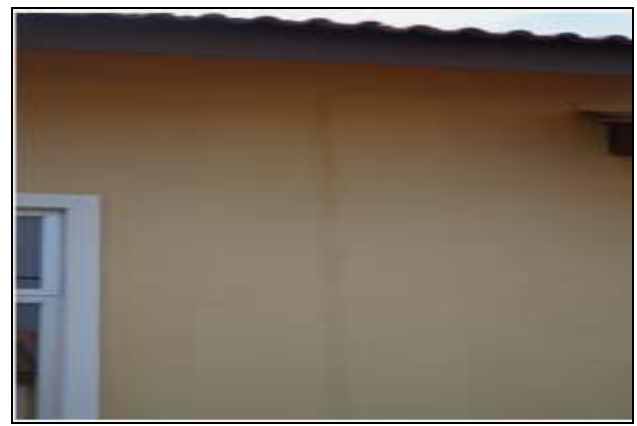

Fig. 3: Vertical cracks on external wall

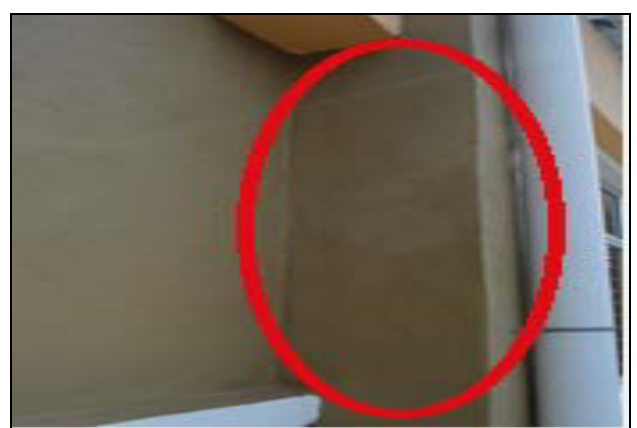

Fig. 4: Diagonal cracks on column area

Figures 1-6 show the existence of vertical and horizontal cracks on external walls and columns as well as peeling paint at a low-cost terrace house and a low cost flat. Cracks, whether they be vertical, horizontal or diagonal, that occur on the structural elements of a building such as walls and columns are common symptoms of structural instability. This might happen due to poor design and workmanship during construction. On the other hand, there were many causes of peeling paint. One of the causes of this is the use of unsuitable types of paint for application on external walls. External walls are the part of a building that is most vulnerable to exposure to harsh weather conditions. Therefore, it is very important to use good quality of paint for such surfaces.

\subsubsection{Flat PPR Paya Nahu}

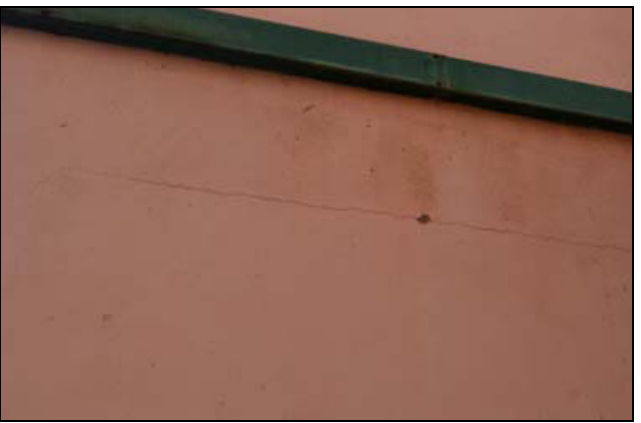

Fig. 5: Plaster cracks on external wall

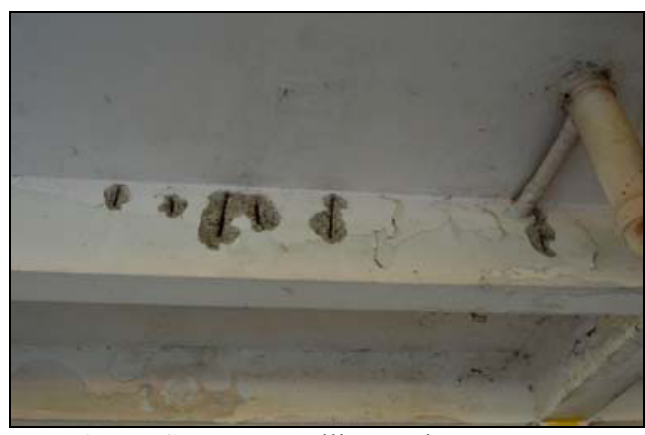

Fig. 7: Concrete spalling on beam area

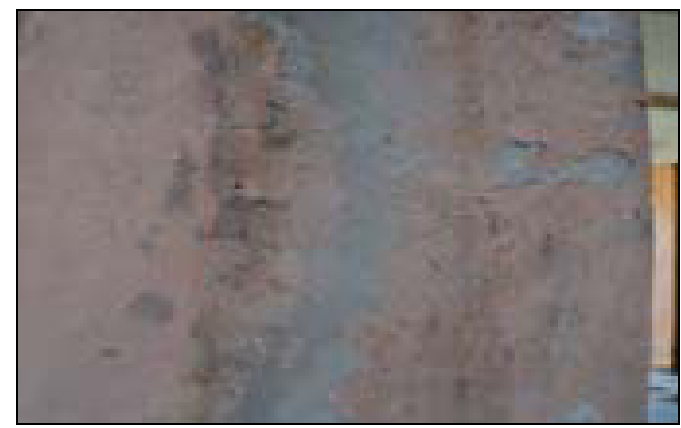

Fig. 6: Severely peeling paint on external wall

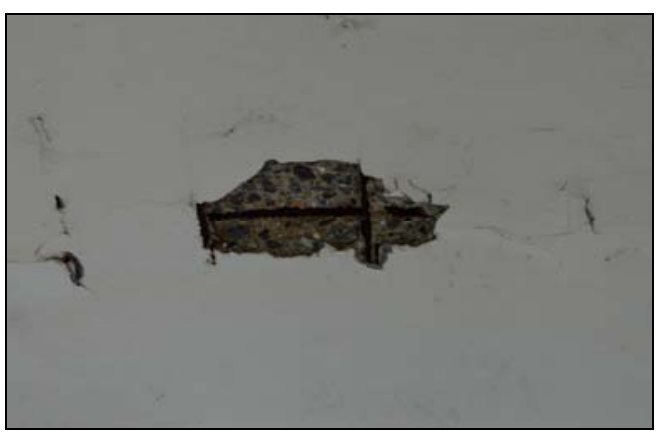

Fig. 8: Concrete spalling underneath the floor slab 


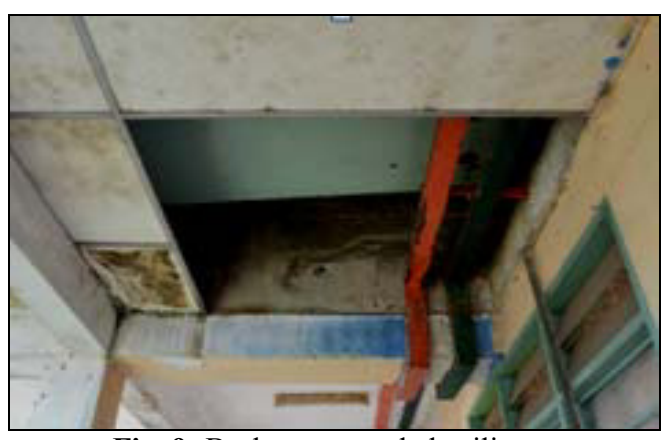

Fig. 9: Broken suspended ceiling

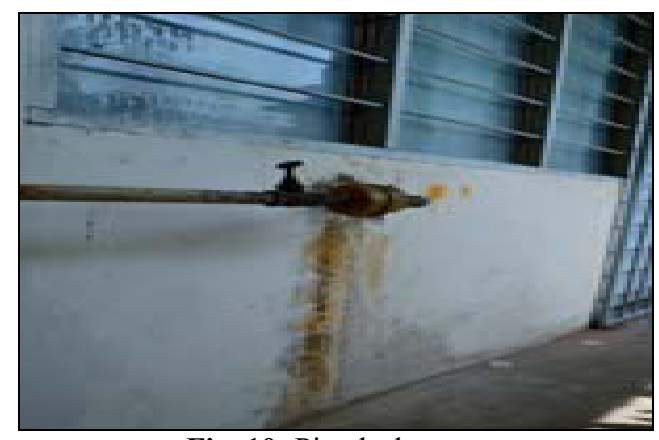

Fig. 10: Pipe leakage

From Fig. 7 and Fig. 8 we can see that there were exposed steel bars on beams and floor slabs on the ground floor of the building. Steel bars were exposed due to the deterioration of steel reinforcements that had been subjected to a harsh environment. The corrosion process of the steel bars was a major source of deterioration to the concrete. This may have occurred due to several factors, one of which is low quality workmanship. In Fig. 9 and Fig. 10, the photos show serious defects on a broken suspended ceiling as well as pipe leakage. The leaking pipe and the damage that occurred to the suspended ceiling may have been caused by improper installation or the ceiling rot may have been due to exposure to water leakage from above the ceiling.

\subsection{Questionnaire Analysis}

\subsubsection{Profession}

Table 1: Number of respondents based on profession

\begin{tabular}{|l|c|c|}
\hline \multicolumn{1}{|c|}{ Profession } & No of Respondent & Percentage, $\%$ (n=180) \\
\hline Architect & 23 & 12.8 \\
\hline Project manager & 28 & 15.6 \\
\hline Quantity surveyor & 22 & 12.2 \\
\hline Building surveyor & 21 & 11.7 \\
\hline Engineer & 24 & 13.3 \\
\hline Contractor & 26 & 14.4 \\
\hline Site supervisor & 36 & 20 \\
\hline Total & $\mathbf{1 8 0}$ & $\mathbf{1 0 0}$ \\
\hline
\end{tabular}

A total of 180 questionnaires were sent to the targeted respondents with a response rate of $100 \%$ as shown in Table 1. From Table 1, it is clear that most of the respondents listed their position as Site Supervisor, Project Manager or Contractor. This is because their scope of work was directly based on the site work and they had relative experiences and expertise in the construction industry.

\subsubsection{Types of Defects Commonly Found in Low-Cost Housing}

Fig. 5 shows the degree to which respondents agreed when asked to choose what types of defects commonly occur on low-cost housing structures and Table 2 shows the percentage of the agreement. As can be seen in Fig. 5 and Table 2, most of the respondents agreed that cracks on walls were the most frequent defects of low-cost housing, with a majority of 77.2 percent of 180 responses. Meanwhile, the least common defects found were faulty electrical fittings, only 8.3 percent out of 180 responses. 


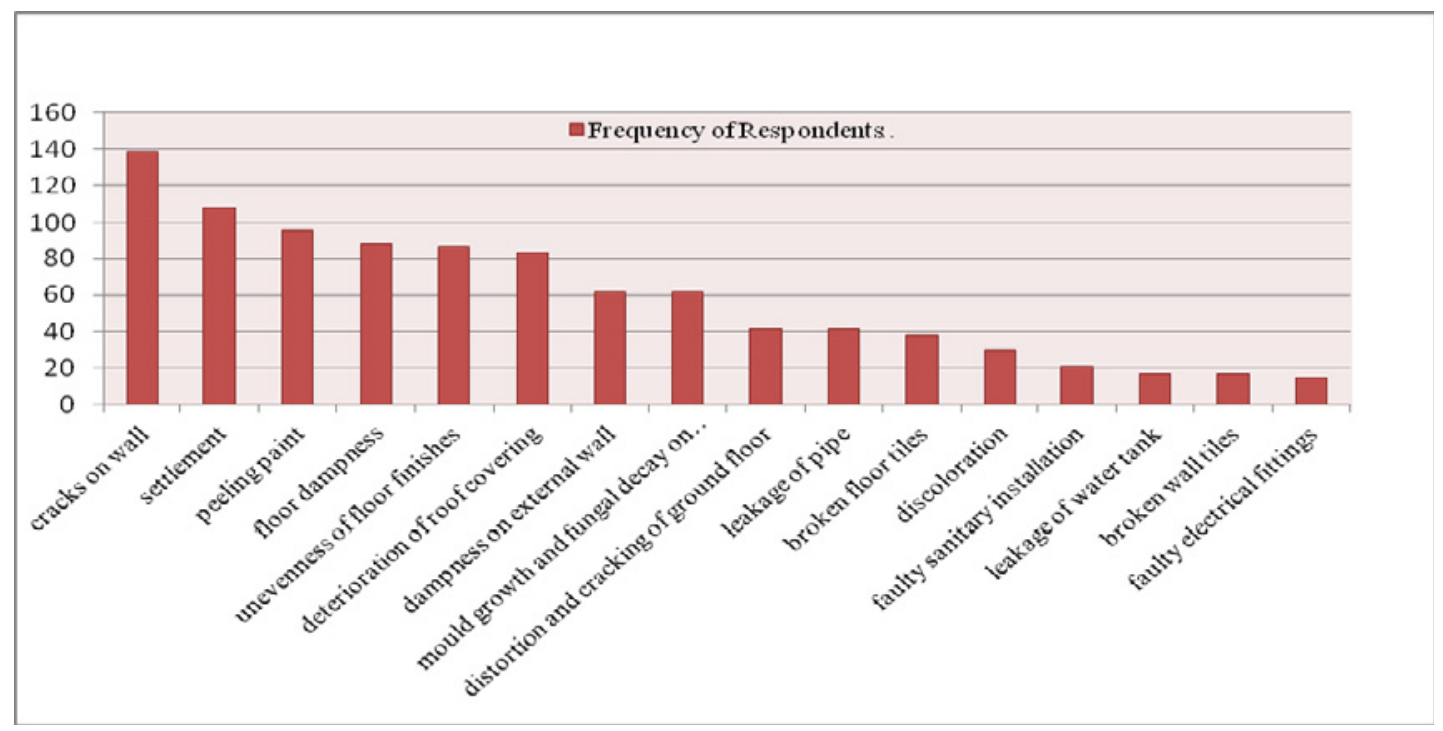

Fig. 5: Common defects on building elements

Table 2: Common defects on building elements

\begin{tabular}{|l|c|c|}
\hline \multicolumn{1}{|c|}{ Types of Defects } & $\begin{array}{c}\text { Frequency of Respondents } \\
\text { Agreement }\end{array}$ & Percentage (\%) \\
\hline Cracks on wall & 139 & 77.2 \\
\hline Settlement & 108 & 60.0 \\
\hline Peeling paint & 96 & 53.3 \\
\hline Floor dampness & 88 & 48.9 \\
\hline Unevenness of floor finishes & 87 & 48.3 \\
\hline Deterioration of roof covering & 83 & 46.1 \\
\hline Dampness on external wall & 62 & 34.4 \\
\hline Mould growth and fungal on external wall & 62 & 34.4 \\
\hline Distortion and cracking of ground floor & 42 & 23.3 \\
\hline Leakage of pipe & 42 & 23.3 \\
\hline Broken floor tiles & 38 & 21.1 \\
\hline Discoloration & 30 & 16.7 \\
\hline Faulty sanitary installation & 21 & 11.7 \\
\hline Leakage of water tank & 17 & 9.4 \\
\hline Broken wall tiles & 17 & 9.4 \\
\hline Faulty electrical fittings & 15 & 8.3 \\
\hline
\end{tabular}

\subsubsection{Contributing Factors to Poor Workmanship}

Table 3: Ranking of factors leading to poor workmanship quality

\begin{tabular}{|l|c|c|}
\hline \multicolumn{1}{|c|}{ Factors Contribute to Poor Workmanship } & Mean & Rank \\
\hline Poor project management & 4.03 & 1 \\
\hline Complex role of subcontractor & 3.41 & 5 \\
\hline Lack of skill and experience/issue of labours competency & 3.89 & 2 \\
\hline Lack of communication/language barrier to communicate & 2.41 & 8 \\
\hline Inappropriate construction equipment & 2.33 & 9 \\
\hline Poor weather condition & 2.73 & 6 \\
\hline Inadequate time & 2.56 & 7 \\
\hline Restricted budget & 3.70 & 3 \\
\hline Unsuitable materials used & 3.54 & 4 \\
\hline
\end{tabular}


Table 3 above indicates the ranking of each factor's priority based on mean readings of the contributing factors of poor workmanship. A calculation of the primary trend using the mean was carried out in order to rank all nine variables. From this data, it was found that poor project management was the most important factor contributing to poor workmanship. The problem in management may be due to insufficient supervision on site [8]. In fact, poor supervision contributes to poor workmanship and it can be seen in many instances on such jobsites [9]. In addition, the ability of management on a construction site is the primary cause that affects labourers' daily productivity [8]. Lack of skills and experience, as well as the issue of labourers' own competency, ranked second highest. Naturally, labourers cannot perform their work well if they do not have any experience or expertise in a certain field [10]. However, inappropriate construction management was rated as the factor having the least effect on poor workmanship [11].

\subsubsection{Possible Measures to Minimize the Problem}

Table 4: Ranking of possible measures to overcome poor quality workmanship

\begin{tabular}{|l|c|c|}
\hline \multicolumn{1}{|c|}{ Effective Measure to Overcome Poor Quality Workmanship } & Mean & Rank \\
\hline Strict supervision & 4.43 & 1 \\
\hline Training and education of labours & 4.16 & 2 \\
\hline Proper communication among parties involved & 3.4 & 5 \\
\hline Suitable construction management & 3.88 & 3 \\
\hline Appropriate manpower management & 3.69 & 4 \\
\hline Accurate and proper design & 3.28 & 6 \\
\hline
\end{tabular}

There were several possible measures that can be implemented in order to overcome the issue of poor quality workmanship in the construction of low-cost housing. Six possible measures are proposed in Table 4 along with their priority rankings. The highest ranking measure that can be used to overcome poor workmanship is strict supervision [12]. Daily supervision should be carried out by the contractors or subcontractors so that workmanship problems can be identified and a remedy can be executed immediately [13]. When actively supervising construction, contractor supervisory staff (site supervisor) must have the knowledge, expertise and capability to monitor and superintend the construction work efficiently. In contrast, accurate and proper design received the lowest ranking of the possible measures [14]. Training and education of labourers was ranked the second highest. Many respondents agreed that appropriate training and sufficient experience is necessary to increase the capability of construction site workers [15]. By doing so, quality construction will result in a quality end product [16]. Other possible measures that can be implemented are suitable construction management, appropriate manpower management and assuring proper communication among parties involved in construction.

\section{Conclusion and Recommendations}

Based on reviews of previous research and analysis of the results, the objectives of this study were achieved. The types of defects which commonly occur on low-cost housing due to poor workmanship were identified, with cracks on walls ranking as the most common defect. Furthermore, there were nine factors listed which contribute to poor workmanship. These factors include poor project management, the complex role of the subcontractor, lack of skills and experience including the issue of labourers' competency, language as a barrier to communication along with lack of communication, unsuitable construction equipment, poor weather conditions, limited time frames, limited costs and unsuitable materials used. From the data collected through the questionnaire surveys, poor project management was ranked as the most significant factor contributing to poor workmanship. In order to overcome this problem, several measures were suggested based on reviews of past research, in which strict supervision was ranked as the most effective measure based on the 
respondents' responses. Apart from that, some recommendations were given by the respondents to minimize the problems of building defects due to poor workmanship. These include monitoring the supply of construction materials to ensure they are up to specifications, using detailed drawings, preventing damages through periodical checking on construction work (by stages), conducting a defects assessment upon completion of building, appropriate budget allocation from the government as to be welfare concept of government to citizen/poor/bottom billion, and, last but not least, selecting procurement and use of quality assessment on building construction work (QLASSIC) developed by CIDB. As a conclusion, this study revealed the factors contributing to poor workmanship and proposed suitable measures that can be implemented by contractors and other parties in the field of construction, especially those involved in low-cost construction in Malaysia to help improve overall performance at every level of management.

\section{Acknowledgement}

The authors would like to thank the funding bodies of this research: Universiti Sains Malaysia under USM Short Term Grant. No. 304/PPBGN/6312147

\section{References}

1. Abdul Rahman, H., Berawi, M.A., Berawi. A.R., Mohamed, O., Othman, M., Yahaya. I.A., 2006. Delay mitigation in the Malaysian construction industry, Journal of Construction Engineering and Management, 132 (2): 125-133

2. Ibrahim, A.R., Matthew, H.R., Ahmed. Z., Imtiaz, G., 2010. An investigation of the status of the Malaysian construction industry, Benchmarking: An International Journal, 17 (2): 294-308

3. M.A. Othuman Mydin, N. Md Sani, M. Taib, N. Mohd Alias, " Imperative Causes of Delays in Construction Projects from Developers' Outlook," MATEC Web Of Conferences, Volume 10, 06005

4. Shittu, A.A., Adamu, A.D., Mohammed, A., Suleiman, B., Isa,R.B., Ibrahim, K., Shehu, M.A., 2013. Appraisal of building defects due to poor workmanship in public building projects in Minna, Nigeria, IOSR Journal of Engineering, 3 (9): 30-38

5. David. S.W., 1999. Building pathology: introduction and practice, John Wiley \& Son, p 41-55

6. Atkinson, A.R. (1999). The role of human error in construction defects, Structural Survey, 17 (4): 231-236

7. Abdul Rahman, H., Thompson, P.A., Whyte, I.L., 1996. Capturing the cost of nonconformance on construction sites- An application of the quality cost matrix, International Journal of Quality \& Reliability Management, 13 (1): 48-60

8. Dai, J., Paul, M.G., William, F.M., 2009. Construction craft workers' perceptions of the factors affecting their productivity, Journal of Construction Engineering and Management, 135 (3): 217-226

9. Kasun, N.H., Janaka, Y.R., 2006. Carpentry workers issues and efficiencies related to construction productivity in commercial construction projects in Alberta. Canadian Journal of Civil Engineering, 33 (2): 1075-1089

10. Ali. A.S., Wen. K.H., 2011. Building defects: possible solution for poor construction workmanship, Journal of Building Performance, 2 (1): 59-69

11. Chan. P.C., Wong. K.W., Lam, T.I., 2006. Assessing quality relationships in public housing. International Journal of Quality \& Reliability Management, 23 (8): 909-927

12. M.A. Othuman Mydin, N. Md Sani, M. Taib, " Industrialised Building System in Malaysia: A Review," MATEC Web Of Conferences, Volume 10, 01002 
13. S.W. Tan, M.A. Othuman Mydin, N. Md Sani, M.Z. Sulieman, "Investigation into Common Decay of Educational Buildings in Malaysia," MATEC Web Of Conferences, Volume 10, 05001

14. Nima, M.A., Abdul-Kadir, M.R., Jaafar. M.S., Riadh, G.A., 2002. Constructability concepts in west port highway in Malaysia. J. of Const. Eng. and Management, 128 (4): 384-356

15. M.A. Othuman Mydin, N. Md Sani, A.F. Phius, "Investigation of Industrialised Building System Performance in Comparison to Conventional Construction Method," MATEC Web Of Conferences, Volume 10, 04001 